\title{
THROMBOCYTOPENIC PURPURA FOLLOWING MEASLES
}

\author{
BY \\ O. D. FISHER and T. M. KRASZEWSKI \\ From The Hospital for Sick Children, Great Ormond Street, London, and Farnborough Hospital
}

(RECEIVED FOR PUBLICATION OCTOBER 3, 1951)

The occurrence of thrombocytopenic purpura as a complication of the acute infectious fevers is uncommon, and two such cases with unusual features which occurred after measles are reported.

\section{Case Reports}

Case 1. C.M., a girl aged 3 years and 7 months, had been in good health until February 6, 1951, when she became unwell with fever and catarrhal symptoms followed three days later by a typical measles eruption. The course of the illness was mild, but on February 17, haemorrhagic vesicles appeared on the tongue followed by bleeding from the gums. Two days later on admission to hospital the child appeared in good general health except for a generalized purpuric rash with ecchymoses of the limbs and petechiae of the buccal, palatal and conjunctival mucosae. Haemorrhagic vesicles were also present on the tonsils: the spleen was not palpable. Thrombocytopenia was present $(14,500$ platelets per c.mm.), with a bleeding time in excess of 10 minutes and poor clot retraction. The urine contained a few red blood cells. There was no family history of any bleeding tendency.

On February 27, a bone marrow aspiration was performed. The megakaryocytes were normal in number, their cytoplasm being, if anything, slightly more condensed than normal. Two further purpuric lesions of the lower lip appeared on February 28, but there was no subsequent purpura or bleeding.

The child remained well although marked thrombocytopenia persisted during the next four weeks (Table 1).

Penicillin, 250,000 units, was given intramuscularly twice a day from February 21 to March 4 because the throat was injected but no pathogenic organisms were cultured. During the following two months there was no further purpura, the platelet count and bleeding time remaining normal.

Case 2. J.P., a girl aged 5 years 10 months, was admitted to hospital on March 29, 1951. One week previously she had developed a mild attack of measles. On the day before admission generalized bruising of the skin and petechial haemorrhages appeared, accompanied by bleeding from the gums and buccal mucosa. The child had also complained of vague pains in the legs for the previous four or five days, associated with anorexia
TABLE 1

Results of Blood Examination in Case 1

\begin{tabular}{|c|c|c|c|c|c|}
\hline Date & $\begin{array}{c}\text { R.B.C. } \\
\text { (per } \\
\text { c.mm.) }\end{array}$ & $\begin{array}{l}\mathrm{Hb} . \\
\left(\begin{array}{l}{ }^{\circ} \\
0\end{array}\right)\end{array}$ & $\begin{array}{c}\text { W.B.C. } \\
\text { (per } \\
\text { c.mm.) }\end{array}$ & $\begin{array}{c}\text { Platelets } \\
\text { (per } \\
\text { c.mm.) }\end{array}$ & $\begin{array}{c}\text { Bleeding } \\
\text { Time } \\
\text { (min.) }\end{array}$ \\
\hline 19.2.51 & $4,620,000$ & 94 & 8,300 & 23,000 & $>10$ \\
\hline 21.2 .51 & & & & 17,200 & \\
\hline 24.2 .51 & $4,610,000$ & & & 23,050 & \\
\hline 26.2 .51 & & & & 18,400 & \\
\hline 28.2 .51 & & & & 29,100 & \\
\hline 2.3 .51 & & & & 42,300 & \\
\hline 7.3 .51 & & & & 63,000 & \\
\hline 10.3 .51 & & & & 40,800 & \\
\hline 15.3 .51 & & & & 45,000 & \\
\hline 5.4 .51 & & & & 484,000 & \\
\hline 4.5 .51 & $4,470,000$ & & & 563,220 & $2 \frac{1}{6}$ \\
\hline
\end{tabular}

Examination of cellular marrow obtained by iliac crest puncture gave :

$\begin{array}{llllll}\text { Granulocytes } & \ldots & \ldots & \ldots & \ldots & \mathbf{2 4}^{\circ}{ }^{\circ} \\ \text { Lymphocytes } & \ldots & \ldots & \ldots & \ldots & \mathbf{4 2}^{\circ}{ }^{\circ} \\ \text { Normoblasts } & \ldots & \ldots & \ldots & \ldots & 3^{\circ}{ }_{0}\end{array}$

and lethargy. There was nothing relevant in the past or family history.

On examination the child was ill with a temperature of $100 \cdot 4^{=}$and a pulse rate of 120 per minute. There were haemorrhagic vesicles on the tongue, a subconjunctival haemorrhage in the right eye and bleeding from the gums. There were multiple petechial haemorrhages in the skin of the trunk and several large fresh bruises on the legs. The spleen and liver were not enlarged but some small cervical glands were palpable. Frank haematuria and heavy albuminuria were present. Hess's capillary resistance test was 
TABLE 2

Results of Serial blood Counts in Case 2

\begin{tabular}{|c|c|c|c|c|c|c|c|c|c|c|c|}
\hline Date & $\begin{array}{l}\mathrm{Hb} \\
(\%)\end{array}$ & $\begin{array}{l}\text { W.B.C. } \\
\text { (per } \\
\text { c.mm.) }\end{array}$ & $\begin{array}{c}\text { Poly- } \\
\text { morphs } \\
(\%)\end{array}$ & $\begin{array}{l}\text { Lymph- } \\
\text { ocytes } \\
(\%)\end{array}$ & $\begin{array}{l}\text { Mono- } \\
\text { cytes } \\
(\%)\end{array}$ & $\begin{array}{l}\text { Turck } \\
\text { Cells } \\
\left({ }^{\prime} \%\right)\end{array}$ & $\begin{array}{l}\text { Baso- } \\
\text { phils } \\
(\%)\end{array}$ & $\begin{array}{l}\text { Eosino- } \\
\text { phils } \\
(\%)\end{array}$ & $\begin{array}{l}\text { Platelets } \\
\text { (per } \\
\text { c.mm.) }\end{array}$ & $\begin{array}{l}\text { Bleeding } \\
\text { Time } \\
\text { (min.) }\end{array}$ & $\begin{array}{l}\text { Reticu- } \\
\text { locytes } \\
(\%)\end{array}$ \\
\hline 30.3 .51 & 67 & 4,000 & 64 & 31 & 5 & & & & 12,000 & $>10$ & \\
\hline \multicolumn{12}{|c|}{ 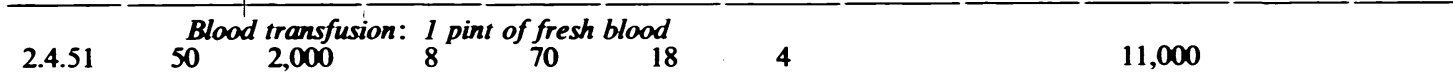 } \\
\hline 3.4 .51 & 42 & 1,700 & $<1$ & 94 & 2 & 4 & & & & & \\
\hline $\begin{array}{l}4.4 .51 \\
5.4 .51\end{array}$ & \multicolumn{10}{|c|}{$\begin{array}{l}\text { Blood transfusion: } 1 \text { pint of fresh and 1 pint of stored blood } \\
94 \\
2,800\end{array}$} & 8 \\
\hline 6.4 .51 & 94 & 2,200 & 18 & 63 & 16 & 3 & & & 44,000 & & \\
\hline 9.4 .51 & 100 & 5,000 & 48 & 46 & 6 & & & & 20,000 & & \\
\hline 12.4 .51 & 98 & 6,000 & 34 & 65 & & 1 & & & 100,000 & & \\
\hline 23.4 .51 & 84 & 9,000 & 37 & 54 & 4 & 1 & 1 & 3 & 230,000 & & \\
\hline 17.7 .51 & 84 & 6,000 & 37 & 51 & 10 & & 1 & 1 & 200,000 & & \\
\hline
\end{tabular}

Examination of cellular marrow obtained by iliac crest puncture gave:

\begin{tabular}{|c|c|c|c|c|c|c|c|c|}
\hline \multirow{2}{*}{\multicolumn{2}{|c|}{ Late normoblasts }} & & & & 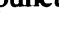 & & & \\
\hline & & $\because$ & $\because$ & $\cdots$ & $\because$ & $\because$ & $\because$ & $59 \cdot 5^{\circ} \%$ \\
\hline Earl & ts & $\therefore$ & .. & .. & . & . & $\therefore$ & $2 \cdot 5^{\circ}{ }^{\circ}$ \\
\hline Lym & $\ldots$ & $\because$ & $\therefore$ & $\ldots$ & $\because$ & $\because$ & $\cdots$ & \\
\hline tes & .. & $\ldots$ & .. & 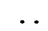 & .. & & .. & \\
\hline & .. & . & $\cdots$ & .. & .. & . & .. & \\
\hline & .. & . & . & $\cdots$ & .. & & 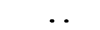 & \\
\hline & & & & . & . & & & $0 \cdot 5^{\circ}$ \\
\hline s: & J.P. & . & .. & .. & .. & & oup & + \\
\hline & $\begin{array}{l}\text { Mother } \\
\text { Father }\end{array}$ & $\cdots$ & & . & $\cdots$ & & $\begin{array}{l}\text { Group } \\
\text { Group }\end{array}$ & $\begin{array}{l}\mathbf{B} \mathbf{K h}+ \\
\mathbf{B} \mathbf{R h}+\end{array}$ \\
\hline
\end{tabular}

The myeloid : erythroblastic ratio was $0 \cdot 2: 1$. Megakaryocytes were present in the usual numbers and showed no morphological changes. There was normoblastic hyperplasia and maturation arrest of polymorphs.

positive. The blood picture and serial blood counts are shown in Table 2.

On the day after admission the child's condition had deteriorated and she was still bleeding from the buccal mucosa and urinary tract. Blood taken for culture was sterile after four days. A diagnosis of thrombocytopenic purpura was made and a pint of fresh maternal blood was transfused. A course of systemic penicillin, 300,000 units daily intramuscularly, was begun on the same day. During the subsequent four days her general condition remained unchanged but oozing from the buccal mucosa and haematuria persisted. There was also considerable bleeding and haematoma formation at the site of transfusion. Daily blood counts showed a steady fall in the haemoglobin level with a marked leucopenia and the development of almost complete agranulocytosis on April 3. For this reason a second transfusion with one pint of paternal blood and one pint of stored blood was given on April 4 with rapid improvement; all bleeding ceased and the blood picture returned to normal during the next few days. Penicillin treatment was stopped on April 11; no other treatment was given. The child was discharged on April 13, and during the following three months she remained well with no recurrence of bleeding.

\section{Comment}

Purpura may present during the course of the acute infectious fevers in three forms. First, it may be confined to the rash where it is probably an exaggeration of the mechanism causing the exanthem. Secondly, it may occur in the haemorrhagic type of these infections when it appears early and is associated with a severe illness which may prove fatal. This is probably due to septicaemia, often streptococcal, rather than to toxaemia from the primary infection. Thirdly, purpura may occur during the period of convalescence from scarlet fever (Box, 1933), rubella (Ackroyd, 1949) and measles (Miller, 1941).

In his review of such cases Miller stated that the measles was usually mild and that purpura occurred during the second week. In the cases described 
by Corbia (1927), Sarrouy (1934), Perlman (1934) and Miller (1941) there was a marked thrombocytopenia during the purpuric phase with a gradual return of the platelets to normal numbers. In that reported by Laurent (1933) there was no decrease of platelets. No bone marrow examinations were recorded.

It is the association of purpura with a preceding infectious fever that is of interest and may pass unrecognized: in Case 1 prolonged thrombocytopenia was present without further haemorrhagic manifestations after the initial phase. In Case 2 the anaemia resulting from severe bleeding from various sites required transfusion on two occasions. The development of an agranulocytosis during the course of the illness has not previously been described.

In both cases the bone marrow was examined during the acute phase of the illness, and normal megakaryocyte formation was present. In Case 2, there was a maturation arrest of the polymorphs.

The mechanism of thrombocytopenia occurring in such cases is obscure, although Ackroyd suggests that it is the result of an allergic response in a susceptible individual.

\section{Summary}

Two cases of thrombocytopenic purpura following mild attacks of measles are described. One patient developed agranulocytosis during the acute haemorrhagic phase.

Bone marrow examination in both instances demonstrated the presence of normal megakaryocytes.

Attention is drawn to the association of thrombocytopenic purpura and the acute infectious fevers.

We wish to thank Dr. G. H. Newns and Dr. J. W. Todd for permission to publish these cases.

\section{REFERENCES}

Ackroyd, J. F. (1949). Quart. J. Med., 18, 299.

Box, C. R. (1933). Lancet, 1, 1217.

Corbia, A. (1927). Clin. pediat., Modena, 9, 779.

Laurent, L. J. M. (1933). Brit. J. Child. Dis., 30, 104. Miller, A. A. (1941). Ibid., 38, 1.

Perlman, E. C. (1934). Arch. Pediat., 51, 596.

Sarrouy, C. (1934). Arch. Méd. Enf., 37, 456. 